\title{
The Promotion of International Cooperation in Common Development and Transformation
}

\author{
Wan Taiyong \\ School of Finance and Public Management, \\ Yunnan University of Finance and Economics \\ Yunnan,P.R.China,650221 \\ 783224799@qq.com
}

\begin{abstract}
The Belt and Road" initiative inherits the spirit of equal openness, peacefulness and inclusiveness on the ancient Silk Road. By putting forward the new cooperation concept of "joint discussion, joint construction, and sharing", China announces the willingness of further expand its opening the world. "The Belt and Road" initiative entails the requirements and principles of international cooperation. Furthermore, "the Belt and Road" initiative represents China's international strategy and the determination of cooperation with countries in the world.
\end{abstract}

Keywords-"the Belt and Road" Initiative, International Cooperation, Development

\section{INTERNATIONAL COOPERATION IS THE CONNOTATION OF}

\section{"THE BELT AND ROAD" INITIATIVE}

"The Belt and Road" initiative entails the requirements and principles of international cooperation. Equality and openness are the preconditions for international cooperation. The leading supply of public goods is the responsibility of large countries in international cooperation. Consultation and coordination and mutual trust and mutual benefit are the basic principles of international cooperation. These constitute the meaning of "the Belt and Road" initiative.

\section{INTERNATIONAL COOPERATION PROMOTES THE}

\section{IMPLEMENTATION OF "THE BELT AND ROAD" INITIATIVE}

\section{A. International cooperation closely connect the regional}

and global development.

With the acceleration of global restructuring and the increasing global challenges, globalization and anti-globalization have interacted with each other. Multilateralism and conservative forces have interwoven each other, global governance and world order reform have moved toward a more just and reasonable direction.

1) International cooperation is the inherent requirement of peaceful development. The world is advancing toward multi-polarization, globalization, and diversification. The demands for international cooperation have multiple levels. Cooperation is the guarantee of peace, and the support of development. It is also the international demand that "the Belt and Road" Initiative tries to respond to.
2) International cooperation is an important method to solve the difficulties of world economic growth. The world economy is still in a period of recovery after the financial crisis. The Euro-zone has not gone out of the predicament of the sovereign debt crisis. Additionally, trade protectionism is gaining momentum. Although emerging economies have played an important role in stimulating world economic growth in the post-financial crisis era, domestic structural contradictions and social issues have affected the follow-up pull. The development of the global economy not only requires new growth drivers, but also requires multi-level, multi-channel and multi-faceted synergistic development and industrial cooperation, promotes liberalization and facilitation of trade and investment, and explores new opportunities for international economic and trade cooperation and development under the new situation.

3) International cooperation is a necessary means of global governance. The overall and complex nature of the international system has been increasingly strengthened, and the intensification of global imbalances has caused global issues such as terrorism, food problems, energy contention, and cybersecurity. The post-Cold War international political practice has proved that international cooperation is the core driving force for the development of the international community. Global issues must seek solutions through international cooperation. In addition, the reform of the global governance system also imposes higher requirements on international cooperation. It is the general trend that the global power has changed and entered into an acceleration period, which will enhance global governance capabilities and promote the reform of the global governance system. Only establishing the deepening cooperation between the developing countries, can promote the reform of international system.

\section{B. International cooperation promotes the connection of national strategies.}

As the provision of international public goods exceeds the capabilities of a country. Only by strengthening international cooperation and co-production to provide public goods through collective actions can fulfill the demand of public goods in the world. By effectively matching these strategic plans through international cooperation and expanding China's development opportunities into common development opportunities for the countries along the route, it will undoubtedly greatly promote the smooth implementation 
of "the Belt and Road" initiative.

1) Achieving the connection of countries in different development stages. The countries along "the Belt and Road" initiative are at different stages of development. There are both developing countries with lower level of industrialization, and developed countries that have leading technologies and high-end equipment. The countries covered by "the Belt and Road" initiative are linked together in the globalization industry chain. The connection of national development strategies through international cooperation, not only meets the infrastructure needs of developing countries, but also beneficial for developed countries to expand exports.

2) Achieving the connection of assistance advantages. China and developed countries jointly to develop a developing country market, which provides an opportunity for the integration of North-South cooperation and South-South cooperation assistance advantages. Trilateral cooperation has become a new form of linking the two models and effectively promoting development cooperation. It not only builds connecting channels for developed countries and emerging countries, but also enhances dialogue and contacts during the transfer and sharing of funds, technology, knowledge and experience.

3) Realizing the interconnection of global technical standards. Technical standardization is not only an important starting point for realizing the interconnection and interoperability of "the Belt and Road" initiative, but also a major support for improving China's opening up level and enhancing its export-oriented economic competitiveness. The cooperation and construction of railway lines, power, ports and other infrastructure with the countries in "the Belt and Road" initiative, can realize the interconnection of the technical standards system.

\section{International cooperation fosters mutually beneficial and win-win partnerships}

The partnership of mutual benefit and win-win results is the expression of the concept of "Community of Interests, Community of Responsibility, and Community of Destiny" advocated by "the Belt and Road" initiative. Cooperation takes the common interests as the premise, and forms the basis of the responsibility community. Economic linkage and social interaction also help the parties to form a community of common prosperity and decline.

1)International cooperation helps expand consensus and promote common interests. Achieving mutual benefit on the basis of cooperation is the fundamental driving force for partnership. The international cooperation under "the Belt and Road" initiative is an important support for China's neighboring countries. The economic corridor has been laid and the common interests of the countries along the route have been laid.
2) Countries share risks and responsibilities under cooperation, and increase mutual trust. Economic interdependence promotes the development of international cooperation, and international cooperation has deepened interdependence. International cooperation is a process. By participating in this process, all countries involved in the cooperation fully understand their own responsibilities and obligations. The trust built through cooperation can inspire all countries to share responsibility for global governance and play their due role in promoting the sustained growth of the world economy and balancing the global political landscape.

3) The spirit of cooperation continues to internalize and spill over to maintain partnerships. International cooperation needs mutual learning. "The Belt and Road" initiative connects countries and regions with different civilizations. It advocates harmonious coexistence and mutual understanding. The concept is constantly internalized in the process of cooperation, enhancing mutual exchanges and interactions, and enhancing mutual recognition and understanding.

\section{THE PRINCIPLE OF INTERNATIONAL COOPERATION UNDER “THE BELT AND ROAD” INITIATIVE}

Over the past few years, the implementation of "the Belt and Road" initiative has achieved a series of cooperation results and will usher in a new round of construction upsurges. Under "the Belt and Road" initiative framework, comprehensive and effective promotion of international cooperation must adhere to the following principles:

1. Insisting the concept of promotion and policy guidance.

2. Insisting the project advancement and mechanism.

3. The coordination of big countries and multiple cooperation are synchronized.

4. Depending on the participation of relevant countries and international organizations.

5. Mode innovation and risk prevention.

\section{REFERENCES}

[1] Djankov, S. (2016). The Rationale Behind China's Belt and Road Initiative. CHINA'S BELT AND ROAD INITIATIVE, 6.

[2] Huang, Y. (2016). Understanding China's Belt \& Road Initiative: Motivation, framework and assessment. China Economic Review, 40, 314-321.

[3] Liu, W., \& Dunford, M. (2016). Inclusive globalization: Unpacking China's belt and road initiative. Area Development and Policy, 1(3), 323-340.

[4] Swaine, M. D. (2015). Chinese views and commentary on the 'One Belt, One Road'initiative. China Leadership Monitor, 47(2), 3.

[5] Wang, Y. (2016). Offensive for defensive: the belt and road initiative and China's new grand strategy. The Pacific Review, 29(3), 455-463.

[6] Weidong, L. (2015). Scientific understanding of the Belt and Road Initiative of China and related research themes. Progress in Geography, 34(5), 538-544. 